\title{
Anaerobic granular sludge as a biocatalyst for 1,3-propanediol production from glycerol in continuous bioreactors
}

\author{
R. Gallardo, C. Faria, L.R. Rodrigues, M.A. Pereira, M.M. Alves* \\ IBB-Institute for Biotechnology and Bioengineering, Centre of Biological Engineering, University of Minho, 4710-057 Braga, Portugal
}

\section{H I G H L I G H T S}

- The production of 1,3-propanediol in EGSB reactors is described for the first time.

- Relatively high 1,3-propanediol yields were obtained without methane production.

- The pre-treatment applied to the biomass has no significant effect at low HRT.

- Anaerobic granular sludge is suitable for the continuous production of 1,3 PDO.

\section{A R T I C L E I N F O}

\section{Article history:}

Received 12 October 2013

Received in revised form 29 November 2013

Accepted 3 December 2013

Available online 12 December 2013

\section{Keywords:}

Anaerobic granular sludge

Glycerol

1,3-Propanediol

HRT

Microbe community structure

\begin{abstract}
A B S T R A C T
1,3-Propanediol (1,3-PDO) was produced from glycerol in three parallel Expanded Granular Sludge Blanket (EGSB) reactors inoculated with granular sludge (control reactor-R1), heat-treated granular sludge (R2) and disrupted granular sludge (R3) at hydraulic retention times (HRT) between 3 and $24 \mathrm{~h}$. Maximum 1,3-PDO yield $\left(0.52 \mathrm{~mol} \mathrm{~mol}^{-1}\right)$ and productivity $\left(57 \mathrm{~g} \mathrm{~L}^{-1} \mathrm{~d}^{-1}\right)$ were achieved in R1 at HRTs of 12 and $3 \mathrm{~h}$, respectively. DGGE profiling of PCR-amplified 16S rRNA gene fragments showed that variations in the HRT had a critical impact in the dominant community of microorganisms. However, no appreciable differences in the bacterial population were observed between R2 and R3 at low HRTs. Production of $\mathrm{H}_{2}$ was observed at the beginning of the operation, but no methane production was observed. This study proves the feasibility of 1,3-PDO production in EGSB reactors and represents a novel strategy to valorise glycerol generated in the biodiesel industry.
\end{abstract}

(c) 2013 Elsevier Ltd. All rights reserved.

\section{Introduction}

The increasing demand for energy, environmental concerns related to fossil fuels use and depletion, together with incentives for biofuels production have led to a rapid growth of worldwide biodiesel production in the last years. As a consequence, a surplus of crude glycerol, a by-product of biodiesel production that represents $10 \% \mathrm{w} / \mathrm{w}$ of the product, has been generated thus creating a glut in the market (Johnson and Taconi, 2007). Furthermore, the disposal of these massive amounts of glycerol became a complex and expensive process, imposing a great pressure in this industry. Since the supply of oils to be converted to biodiesel is becoming increasingly competitive, the profitability of the biodiesel industry will depend on the ability to confer value to its by-products and therefore, the conversion of crude glycerol into other useful products is required (Choi, 2008; Johnson and Taconi, 2007).

The anaerobic biological conversion of glycerol is of interest due to the highly reduced nature of this compound (Choi, 2008). Its

\footnotetext{
* Corresponding author. Tel.: +351253604417.

E-mail address: madalena.alves@deb.uminho.pt (M.M. Alves).
}

fermentation results in the generation of more reducing equivalents when it is converted to glycolytic intermediates as compared with glucose fermentation (Yazdani and Gonzalez, 2007). This excess of reducing equivalents must be oxidized which can be accomplished by the production of $\mathrm{H}_{2}$ and/or via various $\mathrm{NAD}(\mathrm{P}) \mathrm{H}$ consuming pathways towards reduced or neutral end products (Heyndrickx et al., 1991). In fact, glycerol can be converted into several compounds such as citric acid, lactic acid, formic acid, acetic acid, butyric acid, propionic acid, succinic acid, dihydroxyacetone (DHA), 1,3-PDO, dichloro-2-propanol (DCP), acrolein, hydrogen, butanol, ethanol, among others (Choi, 2008; Dharmadi et al., 2006; Yang et al., 2012).

Particularly interesting is 1,3-PDO, a versatile organic chemical used for the production of polyesters, polyethers and polyurethanes. This product is highly specific for glycerol fermentation and cannot be obtained from any other anaerobic conversion (Homann et al., 1990). The metabolic pathways involved in glycerol degradation have been reviewed (da Silva et al., 2009; Saxena et al., 2009). In Klebsiella, Citrobacter, Clostridium and Enterobacter, in the absence of an external oxidant, glycerol is fermented by a dismutation process involving two parallel pathways. The 
production of 1,3-PDO occurs in the reductive pathway that is carried out in two enzymatic steps. The first enzyme coenzyme B12-dependent glycerol dehydratase (EC 4.2.1.30) removes a water molecule from glycerol to form 3-hydroxypropionaldehyde, which is then reduced to 1,3-propanediol by the $\mathrm{NADH}_{2}$-dependent enzyme 1,3-propanediol dehydrogenase (1,3-propanediol-oxydoreductase, EC 1.1.1.202). An exception is C. butyricum, which possesses a vitamin-B12 independent glycerol dehydratase (Saint-Amans et al., 2001). In the oxidative pathway glycerol is transformed in pyruvate which is subsequently converted to various fermentation products depending on the microorganism and culture conditions. Such products include lactate, acetate, ethanol, butyrate, succinate (Choi, 2008), 2,3-butanediol (Saxena et al., 2009), and butanol (Biebl, 2001). Glycerol can also be assimilated by K. pneumoniae via glycerol 3-phosphate (G3P) to pyruvate under aerobic conditions (Choi, 2008; da Silva et al., 2009).

As alternative to pure cultures, 1,3-PDO could be produced using open mixed cultures operated under non-sterile conditions. Expanded granular sludge bed (EGSB) reactors, a system where microorganisms are naturally immobilized, allowing maintaining a high biomass concentration inside the reactors under low hydraulic retention times (HRT), represents an interesting alternative to use open mixed cultures. Even though this kind of system has been widely used to treat wastewater, it has not been fully exploited for the production of added-value compounds from industrial by-products such as glycerol.

The aim of this work was to investigate the production of 1,3PDO from glycerol in EGSB reactors inoculated with granular sludge. Three parallel continuous high-rate EGSB reactors were operated at hydraulic retention times between 3 and $24 \mathrm{~h}$ and glycerol concentration of $25 \mathrm{~g} \mathrm{~L}^{-1}$. A control reactor was inoculated with granular sludge without any treatment (control reactor-R1). In order to test strategies to promote the elimination of methanogens, heat-treated and disrupted granules were used as inoculum in reactors $\mathrm{R} 2$ and $\mathrm{R} 3$, respectively. The microbial community is investigated for the first time in 1,3-PDO producing EGSB reactors.

\section{Methods}

\subsection{Inoculum source}

Granular sludge was obtained from an up-flow anaerobic sludge blanket reactor used to treat brewery wastewater. The water treatment facility is located in Lisbon, Portugal.

\subsection{Experimental procedure}

Two pre-treatments were applied to the granular sludge: heat, which consisted in (i) autoclaving the granular sludge at $100{ }^{\circ} \mathrm{C}$ for $15 \mathrm{~min}$; and (ii) disruption of the granules using a $0.6 \times 25 \mathrm{~mm}$ syringe. Granular sludge without treatment was used as control.

Continuous fermentations were conducted at $37{ }^{\circ} \mathrm{C}$ in three EGSB reactors (working volume of $375 \mathrm{ml}$ ) operated in parallel. Each reactor was inoculated with $100 \mathrm{ml}$ of sludge and fed with a semi-defined culture medium containing per liter; 25 g glycerol, $1 \mathrm{~g}$ yeast extract, $0.5 \mathrm{~g} \mathrm{KH}_{2} \mathrm{PO}_{4}, 0.5 \mathrm{~g} \mathrm{~K}_{2} \mathrm{HPO}_{4}, 0.02 \mathrm{~g} \mathrm{CaCl}_{2} \cdot 2 \mathrm{H} 2 \mathrm{O}$, $0.2 \mathrm{~g} \mathrm{MgSO}_{4} \cdot 7 \mathrm{H}_{2} \mathrm{O}, 3 \mathrm{~g} \mathrm{NaHCO}_{3}, 0.5 \mathrm{~g}$ cysteine- $\mathrm{HCl} \cdot \mathrm{H}_{2} \mathrm{O}, 3 \mathrm{~g} \mathrm{NH}_{4} \mathrm{Cl}$, $1 \mathrm{ml}$ acid micronutrients solution $\left(1.8 \mathrm{~g} \mathrm{~L}^{-1} \mathrm{HCl}, 61.8 \mathrm{mg} \mathrm{L}^{-1}\right.$ $\mathrm{H}_{3} \mathrm{BO}_{3}, 61.3 \mathrm{mg} \mathrm{L}^{-1} \mathrm{MnCl}_{2}, 943.5 \mathrm{mg} \mathrm{L}^{-1} \mathrm{FeCl}_{2}, 64.5 \mathrm{mg} \mathrm{L}^{-1} \mathrm{CoCl}_{2}$, $12.9 \mathrm{mg} \mathrm{L}^{-1} \mathrm{NiCl}_{2}, 67.7 \mathrm{mg} \mathrm{L}^{-1} \mathrm{ZnCl}_{2}$ ) and $1 \mathrm{ml}$ alkaline micronutrients solution $\left(0.4 \mathrm{~g} \mathrm{l}^{-1} \mathrm{NaOH}, 17.3 \mathrm{mg} \mathrm{l}^{-1} \mathrm{Na}_{2} \mathrm{SeO}_{3}, 29.4 \mathrm{mg} \mathrm{L}^{-1}\right.$ $\left.\mathrm{Na}_{2} \mathrm{WO}_{4}, 20.5 \mathrm{mg} \mathrm{L}^{-1} \mathrm{Na}_{2} \mathrm{MoO}_{4}\right)$. Internal liquid recirculation was used in order to keep a suitable expansion of the granules inside the reactor. The initial $\mathrm{pH}$ of the medium was adjusted to 6.8 .
Different HRTs were applied starting with $24 \mathrm{~h}$ and afterwards changing it to 20,12, 6 and $3 \mathrm{~h}$. Steady states were assessed by measuring the concentration of 1,3-PDO.

\subsection{Analytical methods}

Acids, glycerol and 1,3-PDO were measured through high performance liquid chromatography (Jasco, Japan) equipped with UV and RI detectors. The column (Aminex cation-exchange HPX-87H) was eluted isocratically with $\mathrm{H}_{2} \mathrm{SO}_{4} 0.01 \mathrm{~N}$ at $60{ }^{\circ} \mathrm{C}$ using a flow rate of $0.7 \mathrm{ml} \mathrm{min}^{-1}$.

Biogas composition was analyzed by gas chromatography (Chrompack 9001) equipped with a thermal conductivity detector and two columns: Porapack Q (100-180 mesh) $2 \mathrm{~m} \times 1 / 8^{\prime \prime}$ $\times 2.0 \mathrm{~mm}$ SS column, and a MolSieve 5A (80-100 mesh) $1.0 \mathrm{~m} \times 1 / 8^{\prime \prime} \times 2.0 \mathrm{~mm}$ SS. Argon was the carrier gas at a flow rate of $16 \mathrm{ml} \mathrm{min}{ }^{-1}$. The oven, injector and detector temperatures were 35,110 and $110^{\circ} \mathrm{C}$, respectively.

\subsection{Statistical analysis}

The values of yields and productivities were compared among the three reactors for each operating condition. An F-Test TwoSample for Variances was applied and subsequently a $t$-test was used assuming equal or unequal variances.

\subsection{Microbial community analysis}

\subsubsection{DNA Extraction and PCR-DGGE}

For the inoculum and all HRTs studied, representative samples of biomass were collected and stored at $-20{ }^{\circ} \mathrm{C}$ until further treatment. Total genomic DNA was extracted using a FastDNA SPIN kit for soil (Qbiogene, Carlsbad,CA, USA) according to the manufacturer's instructions. The V6-V8 region of bacterial 16S rRNA genes was amplified by PCR using the primers U968GC-f and L1401-r (Nübel et al., 1996). PCR products were separated by DGGE in a polyacrylamide gel ( $8 \%$ ) containing a linear denaturing gradient ranging from $30 \%$ to $60 \%$ (100\%-denaturing solution containing $7 \mathrm{M}$ urea and $40 \%$ formamide) using the DCode System (Bio-Rad Laboratories Inc., CA, USA). Electrophoresis was performed for $16 \mathrm{~h}$ at $85 \mathrm{~V}$ in $0.5 \times \mathrm{TAE}$ buffer at $60^{\circ} \mathrm{C}$. Gels were then stained with silver nitrate and scanned in an Epson Perfection V750 PRO (Epson, USA). Similarity indices (Si) were calculated from the densitometric curves of the scanned DGGE profiles using the Pearson product-moment correlation coefficient (Häne et al., 1993).

\subsubsection{Cloning and sequencing}

Bacterial 16S rRNA genes were amplified by PCR using the primers Bact27-f and 1492-r (Lane, 1991). The PCR products were purified with Nucleo Spin Extract II kit (Clontech Laboratories), ligated into pGEM-T vector (Promega, WI, USA) and introduced into competent Escherichia coli cells E. cloni ${ }^{\circledR} 10 \mathrm{G}$ (Lucigen, WI, USA), according to the manufacturer's instructions. Cells of positive transformants were lysed and the 16S rRNA genes were amplified by PCR using the primers U968GC-f and L1401-r and screened in DGGE by comparison with the band-patterns of the sludge sample (template for cloning). Clones matching different bands in the total community profile were selected for further analysis. Selected clones were amplified using pGEM-T vector-targeted primers SP6/T7, purified with the Nucleo Spin Extract II kit (Clontech Laboratories, USA) and subjected to DNA sequence analysis. Sequencing reactions were performed at Eurofins MWG Operon (Germany). Similarity searches for the 16S rRNA gene sequences were performed using the BLAST search program within the GenBank database (http://www.ncbi.nlm.nih.gov/blast/) (Altschul et al., 1990). 


\section{Results and discussion}

\subsection{1,3-PDO yield and productivity}

Glycerol was mainly converted to 1,3-PDO in all the reactors. Acetate and butyrate were present but in low concentrations ( $<1 \mathrm{~g} / \mathrm{l}$ ), except in R2 when set at an HRT of $12 \mathrm{~h}$ (up to $4 \mathrm{~g} \mathrm{~L}^{-1}$ ) and $\mathrm{R} 1$ at an HRT of $6 \mathrm{~h}\left(1.8 \mathrm{~g} \mathrm{~L}^{-1}\right)$. $\mathrm{pH}$ was kept in the range 5-6 for the retention times of $24-12 \mathrm{~h}$ and decreased to the range 4-5 for the lower hydraulic retention times $(6-3 \mathrm{~h})$. Temudo et al. (2008) worked with CSTR using $4 \mathrm{~g} \mathrm{l}^{-1}$ glycerol at an HRT of $8 \mathrm{~h}, \mathrm{pH} 8$ and found that ethanol and formate were the main products obtained. However, at increasing substrate concentrations, the yields of ethanol and formate decreased, while 1,3-PDO and acetate increased. Fig. 1 presents the time course of glycerol and 1,3-PDO concentration for the three reactors.

It is clear that 1,3-PDO concentration was more stable in R2 and $\mathrm{R} 3$ than in R1.

Table 1 presents the 1,3-PDO yields and productivities for the three reactors and for all the hydraulic retention times applied.

In general, the 1,3-PDO yield was not influenced by the pre-treatment applied to the inoculum. Only for a HRT of $24 \mathrm{~h}$, a statistically different yield was observed between R3 and R2 $(p=0.005)$, and for a HRT of $12 \mathrm{~h}$ between $\mathrm{R} 1$, which produced the highest 1,3-PDO yield, and R3 and R3 ( $p=0.01$ and $p=0.006$, respectively).

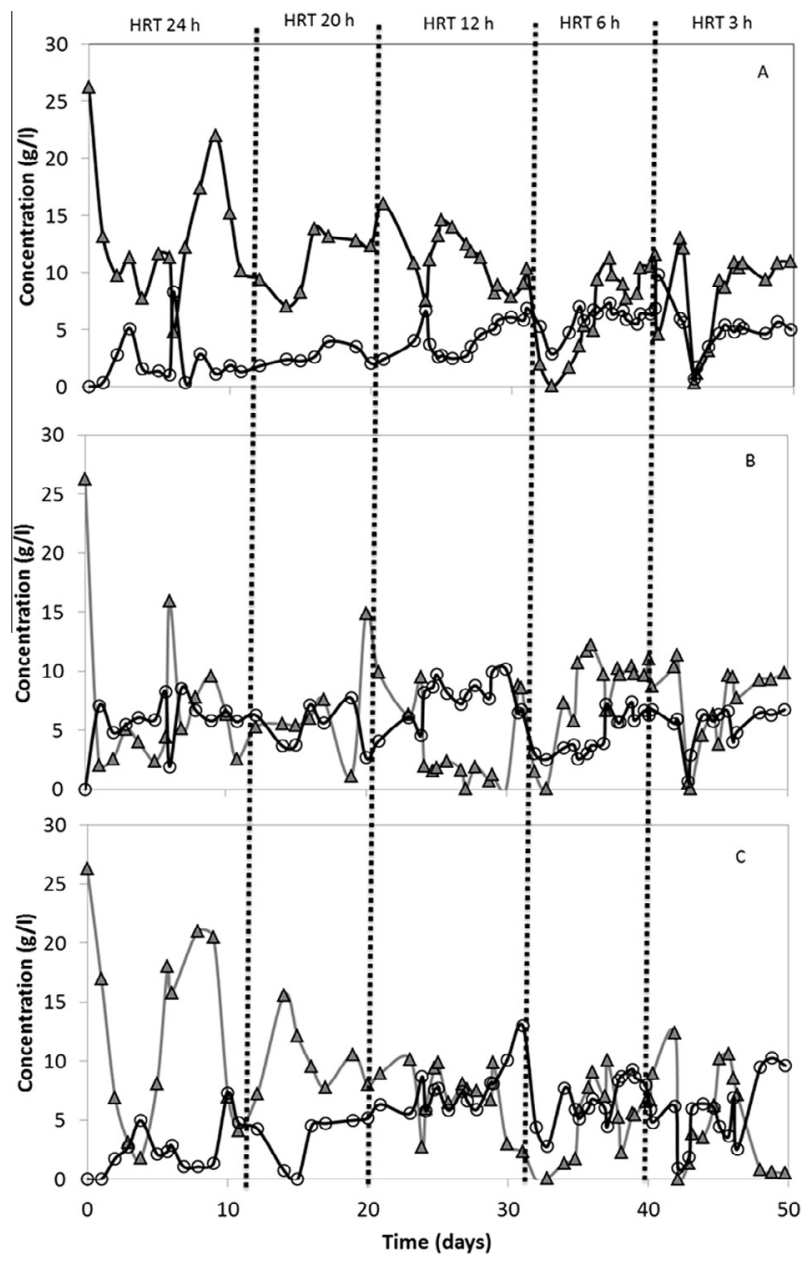

Fig. 1. Effect of HRT on the production of 1,3-PDO in the reactors operated with (a) disrupted granules; (b) heat-treated granules; and (c) non-treated granules. open circles represent 1,3-PDO concentration and grey triangles represent glycerol (Gly) concentrations.
The HRT positively influenced the 1,3-PDO yield that significantly increased from 24 to $6 \mathrm{~h}$. However, for a HRT of $3 \mathrm{~h}$, a decrease in this parameter was observed.

The highest yields of 1,3-PDO from glycerol have been reported for pure cultures of C. butyricum by Saint-Amans et al. (1994) and González-Pajuelo et al. (2005a) corresponding to $0.56 \mathrm{~g} \mathrm{~g}^{-1}$ and $0.65 \mathrm{~mol} \mathrm{~mol}^{-1}$, respectively; and for mixed cultures from wastewater (Selembo et al., 2009) corresponding to $0.69 \mathrm{~mol} \mathrm{~mol}^{-1}$. The maximum theoretical yield for 1,3-PDO in co-production with

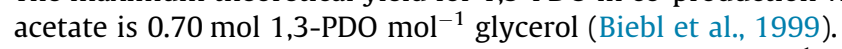

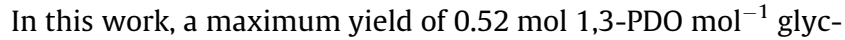
erol was achieved. The results showed the same metabolic profile as the one described by González-Pajuelo et al. (2005a), in which 1, 3-PDO production is significantly lower when $\mathrm{H}_{2}$ is being produced. Also, the maximum 1,3-PDO yield reported by Saint-Amans et al. (1994) was obtained without any $\mathrm{H}_{2}$ production.

Concerning the volumetric productivity of 1,3 PDO, a maximum value was obtained in R1 at a HRT of $3 \mathrm{~h}$, significantly higher than the one obtained in R3 ( $p=0.03)$, but not significantly higher than $\mathrm{R} 2$. In general, the volumetric productivity 1,3-PDO in R1 was higher than in the reactor inoculated with R3 $(p=0.02,0.008,0.008$, 0.05 , and 0.03 , for HRT of $24,20,12,6$ and $3 \mathrm{~h}$, respectively). The difference in productivity between R2 and R1 was only significant for a HRT of $24 \mathrm{~h}(p=0.0003)$ and HRT of $6 \mathrm{~h}(p=0.02)$. R2 showed significantly higher productivities than R3 for a HRT of 24, 20 and $12 \mathrm{~h}$ ( $p<0.0001, p=0.04$ and $p=0.0008$, respectively).

The values of 1,3-PDO productivity can be compared with literature values obtained with pure cultures (Table 2). Two new approaches for the production of 1,3-PDO have been reported. Kumar et al. (2013) developed a mutant strain of Klebsiella pneumoniae deficient in lactate dehydrogenase $\left(I d h A^{-}\right)$and overexpressing an aldehyde dehydrogenase (KGSADH). The authors studied the co-production of 3-Hydroxypropionic acid (3-HP) and 1,3-PDO from glycerol by this recombinant under resting cell conditions. Besides eliminating the production of lactate, the authors reported an improvement of $30 \%$ and $50 \%$ in the production of 3-HP and 1,3-PDO, respectively, in comparison with the wild type strain. The final titers of 3-HP and PDO by the recombinant strain at $60 \mathrm{~h}$ were $252.2 \mathrm{mM}$ and $308.7 \mathrm{mM}$, respectively. Kaur et al. (2013) developed a mathematical model-based nutrient feeding approach for high production of 1,3-PDO in fed-batch culture with Clostridium diolis DSM15410, using average batch kinetics and independently obtained inhibition data which reflected both the substrate limitation/inhibitions and the product inhibitions during the dynamic cultivation process By using this this cultivation strategy, the authors demonstrated an improvement not only in the final concentration of 1,3-PDO achieved $\left(63.5 \mathrm{~g} \mathrm{~L}^{-1} \mathrm{vs} 25.8 \mathrm{~g} \mathrm{~L}^{-1}\right.$ in batch) but also in the 1,3-PDO productivity, which achieved $1.35 \mathrm{~g} \mathrm{~L}^{-1} \mathrm{~h}^{-1}$ (as compared to $0.72 \mathrm{~g} \mathrm{~L}^{-1} \mathrm{~h}^{-1}$ in batch cultivation).

\subsection{Gas composition}

Biogas composition revealed that methane was not produced at any of the HRT tested, thus meaning that the operating conditions were unfavourable to methanogenic archaea. This result is in agreement with the work reported by Selembo et al. (2009) that did not observe methane production working in batch with heat-treated inocula using glycerol as carbon source. $\mathrm{H}_{2}$ was only detected at the HRT of $24 \mathrm{~h}$ in R1 and R2 at $13 \%$ and 39\%, respectively. The production of $\mathrm{H}_{2}$ and 1,3-PDO are competing pathways in terms of reducing equivalents. For example in Clostridium sp. the reducing equivalents generated in the conversion of pyruvate to Acetyl CoA are used to reduce ferredoxin, which is re-oxidized through the production of $\mathrm{H}_{2}$ by hydrogenases. If no or less $\mathrm{H}_{2}$ is formed, those reducing equivalents should be available for the production other reduced compounds such as 1,3-PDO. Temudo et al. 
Table 1

1,3-PDO yield and volumetric productivity.

\begin{tabular}{|c|c|c|c|c|c|c|}
\hline \multirow[t]{2}{*}{ HRT (h) } & \multicolumn{3}{|c|}{ 1,3-PDO yield (mol 1,3-PDO. $\mathrm{mol}^{-1}$ glycerol) } & \multicolumn{3}{|c|}{ 1,3-PDO productivity (g 1,3-PDO. $\mathrm{L}^{-1} \mathrm{~d}^{-1}$ ) } \\
\hline & Disrupted & Heat treated & Control & Disrupted & Heat treated & Control \\
\hline 24 & $0.21 \pm 0.14$ & $0.39 \pm 0.07$ & $0.31 \pm 0.09$ & $1.5 \pm 0.33$ & $6.7 \pm 1.1$ & $3.2 \pm 2.1$ \\
\hline 20 & $0.29 \pm 0.08$ & $0.37 \pm 0.05$ & $0.36 \pm 0.05$ & $3.6 \pm 1.1$ & $7.0 \pm 2.2$ & $6.2 \pm 0.90$ \\
\hline 12 & $0.39 \pm 0.08$ & $0.42 \pm 0.05$ & $0.52 \pm 0.08$ & $11.7 \pm 1.3$ & $16.6 \pm 2.7$ & $16.2 \pm 4.2$ \\
\hline 6 & $0.46 \pm 0.08$ & $0.47 \pm 0.05$ & $0.44 \pm 0.07$ & $26.9 \pm 4.2$ & $25.8 \pm 2.7$ & $30.9 \pm 4.8$ \\
\hline 3 & $0.39 \pm 0.04$ & $0.37 \pm 0.08$ & $0.40 \pm 0.07$ & $39.5 \pm 5.2$ & $45.1 \pm 7.8$ & $56.9 \pm 16.8$ \\
\hline
\end{tabular}

Table 2

Data of yield and productivity of 1,3 PDO from glycerol obtained in this work and from literature.

\begin{tabular}{|c|c|c|c|c|c|c|}
\hline Microorganism & $\mathrm{D}\left(\mathrm{h}^{-1}\right)$ & $\begin{array}{l}\text { Glycerol } \\
\text { feeding }\left(\mathrm{g} \mathrm{L}^{-1}\right)\end{array}$ & $\begin{array}{l}\text { 1,3-PDO yield } \\
\left(\mathrm{mol} \mathrm{mol}^{-1}\right)\end{array}$ & $\begin{array}{l}\text { 1,3-PDO } \\
\text { Productivity ( } \mathrm{g} \mathrm{L}^{-1} \\
\mathrm{~d}^{-1} \text { ) }\end{array}$ & Reference & Culture system \\
\hline \multirow{5}{*}{$\begin{array}{l}\text { Undefined mixed culture (granular } \\
\text { sludge) }\end{array}$} & 0.04 & 25 & $0.31 \pm 0.09$ & $3.2 \pm 2.1$ & This work & EGSB reactor \\
\hline & 0.05 & 25 & $0.36 \pm 0.05$ & $6.2 \pm 0.90$ & & \\
\hline & 0.08 & 25 & $0.52 \pm 0.08$ & $16.2 \pm 4.2$ & & \\
\hline & 0.17 & 25 & $0.44 \pm 0.07$ & $30.9 \pm 4.8$ & & \\
\hline & 0.33 & 25 & $0.40 \pm 0.07$ & $56.9 \pm 16.8$ & & \\
\hline \multirow{5}{*}{$\begin{array}{l}\text { Undefined mixed culture } \\
\quad \text { (heat-treated granular sludge) }\end{array}$} & 0.04 & 25 & $0.39 \pm 0.07$ & $6.7 \pm 1.1$ & & \\
\hline & 0.05 & 25 & $0.37 \pm 0.05$ & $7.0 \pm 2.2$ & & \\
\hline & 0.08 & 25 & $0.42 \pm 0.05$ & $16.6 \pm 2.7$ & & \\
\hline & 0.17 & 25 & $0.47 \pm 0.05$ & $25.8 \pm 2.7$ & & \\
\hline & 0.33 & 25 & $0.37 \pm 0.08$ & $45.1 \pm 7.8$ & & \\
\hline \multirow{5}{*}{$\begin{array}{l}\text { Undefined mixed culture } \\
\quad \text { (disrupted granular sludge) }\end{array}$} & 0.04 & 25 & $0.21 \pm 0.14$ & $1.5 \pm 0.33$ & & \\
\hline & 0.05 & 25 & $0.29 \pm 0.08$ & $3.6 \pm 1.1$ & & \\
\hline & 0.08 & 25 & $0.39 \pm 0.08$ & $11.7 \pm 1.3$ & & \\
\hline & 0.17 & 25 & $0.46 \pm 0.08$ & $26.9 \pm 4.2$ & & \\
\hline & 0.33 & 25 & $0.39 \pm 0.04$ & $39.5 \pm 5.2$ & & \\
\hline \multirow[t]{2}{*}{ Clostridium butyricum VPI 3266} & 0.4 & 30 & 0.6 & 132 & $\begin{array}{l}\text { Gonzalez-Pajuelo } \\
\text { et al. (2005a) }\end{array}$ & $\begin{array}{l}\text { Single stage continuous } \\
\text { culture }\end{array}$ \\
\hline & 0.3 & 60 & 0.65 & 247.2 & & \\
\hline Klebsiella pneumoniae DSM 2026 & $0.1-0.25$ & na & na & $117.6-211.2$ & Menzel et al. (1997) & $\begin{array}{l}\text { Anaerobic fixed bed reactor } \\
\text { with effluent recycle }\end{array}$ \\
\hline Clostridium butyricum F2b & $0.11-0.04$ & 90 & 0.59 (global) & 31.92 (global) & $\begin{array}{l}\text { Papanikolaou et al. } \\
\text { (2008) }\end{array}$ & $\begin{array}{l}\text { Two-stage continuous culture } \\
\text { (CSTR) }\end{array}$ \\
\hline Citrobacter freundii DSM 30040 & 0.5 & 36.8 & 0.57 & 196.8 & $\begin{array}{l}\text { Pflugmacher and } \\
\text { Gottschalk (1994) }\end{array}$ & $\begin{array}{l}\text { Anaerobic fixed bed reactor } \\
\text { with effluent recycle }\end{array}$ \\
\hline $\begin{array}{l}\text { Clostridium acetobutylicum DG1 } \\
\text { (pSPD5) }\end{array}$ & 0.05 & 60 & 0.64 & 72 & $\begin{array}{l}\text { Gonzalez-Pajuelo } \\
\text { et al. (2005b) }\end{array}$ & $\begin{array}{l}\text { Single stage continuous } \\
\text { culture CSTR }\end{array}$ \\
\hline \multirow[t]{11}{*}{ Clostridium butyricum DSM 5431} & 0.31 & 30.39 & 0.65 & 74.4 & Reimann et al. (1998) & $\begin{array}{l}\text { Continuous culture with cell } \\
\text { recycling }\end{array}$ \\
\hline & 0.31 & 30.21 & 0.57 & 100.8 & & \\
\hline & 0.49 & 30.76 & 0.60 & 168 & & \\
\hline & 0.70 & 34.07 & 0.59 & 228 & & \\
\hline & 0.97 & 34.99 & 0.65 & 172.8 & & \\
\hline & 0.20 & 57.10 & 0.60 & 100.8 & & \\
\hline & 0.30 & 57.65 & 0.58 & 187.2 & & \\
\hline & 0.50 & 55.25 & 0.63 & 319.2 & & \\
\hline & 0.72 & 55.62 & 0.63 & 393.6 & & \\
\hline & 0.99 & 57.19 & 0.61 & 266.4 & & \\
\hline & 1.00 & 56.17 & 0.61 & 606.1 & & \\
\hline
\end{tabular}

(2008) reported almost negligible production of $\mathrm{H}_{2}(0.4 \%$ of the products) working in CSTR using an HRT of $8 \mathrm{~h}, \mathrm{pH} 8$ and glycerol as the carbon source. These results point to a shift in the overall metabolism that can be explained by the selection process that occurs through the different HRTs. It is worth to note that hydrogen-consuming microorganisms, such as acetogenic bacteria, can survive to heat treatment (Oh et al., 2003).

\subsection{Microbial community profiles}

The results obtained by DGGE clearly show that the bacterial community changed significantly through the different HRTs applied (Fig. 2). The profiles of the heat-treated, disrupted and non-treated biomass collected at the lowest HRT tested, i.e. $3 \mathrm{~h}$, exhibited a similarity to the correspondent inocula of only $29.5 \%$ $(\mathrm{H} 3 \mathrm{~h} / \mathrm{InH}), 21.4 \%(\mathrm{D} 3 \mathrm{~h} / \mathrm{InD})$ and $18.2 \%(\mathrm{C} 3 \mathrm{~h} / \mathrm{InC})$, respectively (Fig. 2b).

Comparing samples from the different reactors it is perceptible that the bacterial community evolved differently according to the initial treatment. It is worth noticing that the reactor that exhibited the highest 1,3-PDO volumetric productivity, operated with nontreated biomass at an HRT of $3 \mathrm{~h}$ (sample C3h), showed a bacterial profile considerably different from the other two (samples $\mathrm{H} 3 \mathrm{~h}$ and D3h) (Fig. 2). Bands corresponding to microorganisms related to 
(a)
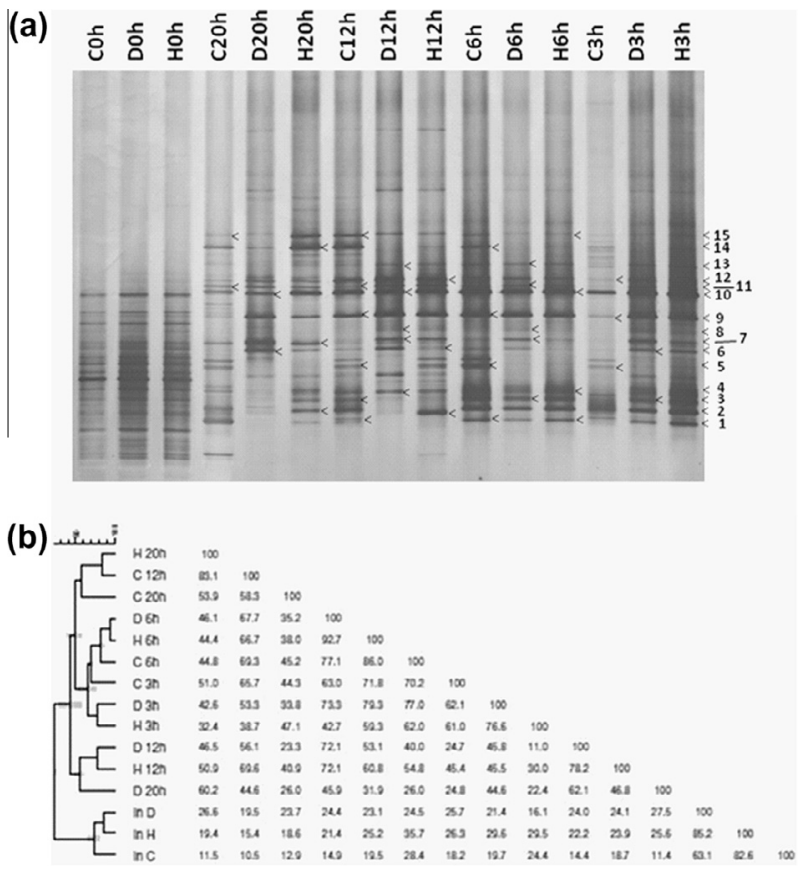

Fig. 2. Bacterial DGGE profile (a) of the granular sludge at times $0,20,12,6$ and $3 \mathrm{~h}$ for the reactors operated with non-treated biomass (C), disrupted biomass (D) and heat-treated biomass $(\mathrm{H})$ and corresponding similarity indices (in \%) dendogram (UPGA clustering) and matrix (b). Numbers 1 to 15 marks the band position of the sequenced 16S RNA genes.

Table 3

Affiliations of the cloned 16S rRNA gene sequences.

\begin{tabular}{|c|c|}
\hline $\begin{array}{l}\text { Band } \\
\text { ID }\end{array}$ & Closest relatives (\% sequence similarity) \\
\hline 1 & Lactobacillus delbrueckii (99\%) \\
\hline 2 & $\begin{array}{l}\text { Uncultured bacterium clone VHW_F_D1 (99\%), Lactobacillus } \\
\text { delbrueckii (99\%) }\end{array}$ \\
\hline 3 & Lactobacillus parabuchneri (99\%) \\
\hline 4 & $\begin{array}{l}\text { Uncultured bacterium clone MY33 (99\%), Lactobacillus delbrueckii } \\
\text { (99\%) }\end{array}$ \\
\hline 5 & $\begin{array}{l}\text { Uncultured bacterium clone Ta_1_28 (98\%), Clostridium } \\
\text { tyrobutyricum (95\%) }\end{array}$ \\
\hline 6 & $\begin{array}{l}\text { Uncultured bacterium clone inf86 (99\%), Enterococcus canintestis } \\
(99 \%)\end{array}$ \\
\hline 7 & $\begin{array}{l}\text { Uncultured bacterium clone inf86 (99\%), Enterococcus canintestis } \\
(99 \%)\end{array}$ \\
\hline 8 & Enterobacteriaceae bacterium A52 (99\%), Klebsiella sp. Gx17 (97\%) \\
\hline 9 & Enterobacteriaceae bacterium A52 (99\%), Enterobacter sp. LB9 (98\%) \\
\hline 10 & $\begin{array}{l}\text { Uncultured bacterium clone VHW_F_D1 (99\%), Lactobacillus } \\
\text { parabuchneri (99\%) }\end{array}$ \\
\hline 11 & $\begin{array}{l}\text { Uncultured bacterium clone F2V (99\%), Vagococcus salmoninarum } \\
(99 \%)\end{array}$ \\
\hline 12 & $\begin{array}{l}\text { Uncultured bacterium clone RB-3A5 (98\%), Vagococcus carniphitus } \\
\text { (97\%) }\end{array}$ \\
\hline 13 & $\begin{array}{l}\text { Uncultured bacterium clone RB-3A5 (98\%), Vagococcus } \\
\text { salmoninarum (99\%) }\end{array}$ \\
\hline 14 & Clostridium butyricum (NCIMB8082) (99\%) \\
\hline 15 & Clostridium butyricum strain AB33 (99\%) \\
\hline
\end{tabular}

Enterococcus (band 6 and 7), Klebsiella (band 8) and Enterobacter (bands 9) had a lower relative dominance in sample $\mathrm{C} 3 \mathrm{~h}$, some being undetectable. Two rybotypes closely affiliated to Lactobacillus-like organisms (bands 2 and 10) seem to dominate in this bacterial community. Other bacterial 16S rRNA gene sequences retrieved from the sludge samples were closely related (similarity $>97 \%$ ) to those of members of the genus Vagococcus (11, 12 and 13), Clostridium (bands 14 and 15) and to uncultured bacteria from the Clostridiaceae family (band 5) (Table 3).
Even though members of all these genera have been reported as able to metabolize glycerol, the production of 1,3-PDO has not been proved for some of the species herein identified. As example, Lactobacillus delbrueckii has shown to produce considerable amounts of lactic acid from glycerol and minor quantities of acetic acid (Choubisa et al., 2012).

Among the microorganisms herein detected known for producing 1,3-PDO, C. butyricum NCIMB8082 (99\%), C. butyricum strain AB33 (99\%), and Lactobacillus were the most representative. Lactobacillus panis PM1 was reported to be a 1,3-PDO producer from bioethanol thin stillage and L. coryniformis and L. parabuchneri produced 1,3- and 1,2-propanediol from glycerol and lactate, respectively (Khan et al., 2013; Sekwati-Monang et al., 2012). Regarding Enterobacteriaceae, it has been pointed out that anaerobic growth in glycerol and formation of 1,3-PDO is used as a characteristic mark for identification of the genus Citrobacter, but it is also found in strains of Klebsiella (Toraya et al., 1980). Furthermore, it has been also described that some lactic acid bacteria produce 1,3-PDO from glycerol if both a growth and energy substrate is present in the medium (Schütz and Radler, 1984).

\section{Conclusion}

Continuous production of 1,3-PDO from glycerol in EGSB reactors is described for the first time. The production yield $(0.52 \mathrm{~mol}$ 1,3-PDO $\mathrm{mol}^{-1}$ glycerol) is not as high as the values reported for pure cultures, however the advantage herein is that fermentations are conducted in non-sterile conditions, which has the potential of significantly decreasing the operational costs. Furthermore, the conditions used resulted in the absence of methane production. The results obtained suggest that at low retention times the pretreatment applied to the biomass has no significant effect, being anaerobic granular sludge a suitable catalyst for the continuous production of 1,3-PDO.

\section{Acknowledgement}

The financial support given to Roberto Gallardo from Fundação da Ciência e da Tecnologia (ref SFRH/BD/42900/2008) is gratefully acknowledged. The authors thank the MIT-Portugal Program for the support given to R. Gallardo and C. Faria.

\section{References}

Altschul, S.F., Gish, W., Miller, W., Meyers, E.W., Lipman, D.J., 1990. Basic local alignment search tool. J. Mol. Biol. 215, 403-410.

Biebl, H., Menzel, K., Zeng, A., Deckwer, W., 1999. Microbial production of 1,3propanediol. Appl. Microbiol. Biotechnol. 52, 289-297.

Biebl, H., 2001. Fermentation of glycerol by Clostridium pasteurianum - batch and continuous culture studies. J. Ind. Microbiol. Biotechnol. 27, 18-26.

Choi, W.J., 2008. Glycerol-based biorefinery for fuels and chemicals. Recent Pat. Biotechnol. 2, 173-180.

Choubisa, B., Patel, H., Patel, M., Dholakiya, B., 2012. Microbial production of lactic acid by using crude glycerol from biodiesel. J. Microbiol. Biotech. Res. 2 (1), $90-$ 93.

da Silva, G., Mack, M., Contiero, J., 2009. Glycerol: a promising and abundant carbon source for industrial microbiology. Biotechnol. Adv. 27, 30-39.

Dharmadi, Y., Murarka, A., Gonzalez, R., 2006. Anaerobic fermentation of glycerol by Escherichia coli: a new platform for metabolic engineering. Biotechnol. Bioeng. 94, 821-829.

González-Pajuelo, M., Andrade, J., Vasconcelos, I., 2005a. Production of 1,3propanediol by Clostridium butyricum VPI 3266 in continuous cultures with high yield and productivity. J. Ind. Microbiol. Biotechnol. 32 (9), 391-396.

Gonzalez-Pajuelo, M., Meynial-Salles, I., Mendes, F., Andrade, J., Vasconcelos, I., Soucaille, P., 2005b. Metabolic engineering of Clostridium acetobutylicum for the industrial production of 1,3-propanediol from glycerol. Metab. Eng. 7, 329-336.

Häne, B.G., Jäger, K., Drexler, H., 1993. The Pearson product-moment correlation coefficient is better suited for identification of DNA fingerprint profiles than band matching algorithms. Electrophoresis 14, 967-972.

Heyndrickx, M., De Vos, P., Vancanneyt, M., De Ley, J., 1991. The fermentation of glycerol by C. butyricum LMG $1212 \mathrm{t} 2$ and $1213 \mathrm{t} 1$ and C. pasteurianum LMG 3285. Appl. Microbiol. Biotechnol. 34, 637-642. 
Homann, T., Tag, C., Biebl, H., Deckwer, W.-D., Schink, B., 1990. Fermentation of glycerol to 1,3-propanediol by Klebsiella and Citobacter strains. Appl. Microbiol. Biotechnol. 33, 121-126.

Johnson, D., Taconi, K., 2007. The glycerin glut: options for the value-added conversion of crude glycerol resulting from biodiesel production. Environ. Prog. 26 (4), 338-348.

Kaur, G., Srivastava, A.K., Chand, S., 2013. Bioconversion of glycerol to 1,3propanediol: a mathematical model-based nutrient feeding approach for high production using Clostridium diolis. Bioresour. Technol. 142, 82-87.

Khan, N.H., Kang, T.S., Grahame, D.A., Haakensen, M.C., Ratanapariyanuch, K., Reaney, M.J., Korber, D.R., Tanaka, T., 2013. Isolation and characterization of novel 1,3-propanediol-producing Lactobacillus panis PM1 from bioethanol thin stillage. Appl. Microbiol. Biotechnol. 97 (1), 417-428.

Kumar, V. et al., 2013. Simultaneous production of 3-hydroxypropionic acid and 1,3-propanediol from glycerol using resting cells of the lactate dehydrogenasedeficient recombinant Klebsiella pneumoniae overexpressing an aldehyde dehydrogenase. Bioresour. Technol. 135, 555-563.

Lane, D.J., 1991. 16S/23S rRNA sequencing. In: Stackebrandt, E., Goodfellow, M (Eds.), Nucleic Acid Techniques in Bacterial Systematics. John Wiley \& Sons, Chichester.

Menzel, K., Zeng, A., Deckwer, W., 1997. High concentration and productivity of 1,3 propanediol from continuous fermentation of glycerol by Klebsiella pneumoniae. Enzyme Microb. Tech. 20, 82-86.

Nübel, U., Engelen, B., Felske, A., Snaidr, J., Wieshuber, A., Amann, R.I., et al., 1996. Sequence heterogeneities of genes encoding 16S rRNAs in Paenibacillus polymyxa detected by temperature-gradient gel electrophoresis. J. Bacteriol. $178,5636-5643$.

Oh, S., Van Ginkel, S., Logan, B., 2003. The relative effectiveness of pH control and heat treatment for enhancing biohydrogen gas production. Environ. Sci. Technol. 37, 5186-5190.

Papanikolaou, S., Fakas, S., Fick, M., Chevalot, I., Galiotou-Panayotou, M., Komaitis, M., Marc, I., Aggelis, G., 2008. Biotechnological valorisation of raw glycerol discharged after bio-diesel (fatty acid methyl esters) manufacturing process: production of 1,3-propanediol, citric acid and single cell oil. Biomass Bioenerg. $32,60-71$.
Pflugmacher, U., Gottschalk, G., 1994. Development of an immobilized cell reactor for the production of 1,3-propanediol by Citrobacter freundii. Appl. Microbiol Biotechnol. 41, 313-316.

Reimann, A., Biebl, H., Deckwer, W., 1998. Production of 1,3-propanediol by Clostridium butyricum in continuous culture with cell recycling. Appl. Microbiol. Biotechnol. 49, 359-363.

Saint-Amans, S., Perlot, P., Goma, G., Soucaille, P., 1994. High production of 1,3propanediol from glycerol by Clostridium butyricum VPI 3266 in a simply controlled fed-batch system. Biotechnol. Lett. 16, 831-836.

Saint-Amans, S., Girbal, L., Andrade, J., Ahrens, K., Soucaille, P., 2001. Regulation of carbon and electron flow in Clostridium butyricum VPI 3266 grown on glucoseglycerol mixtures. J. Bacteriol. 183, 1748-1754.

Saxena, R.K., Anand, P., Saran, S., Isar, J., 2009. Microbial production of 1,3propanediol: recent developments and emerging opportunities. Biotechnol. Adv. 27 (6), 895-913.

Schütz, H., Radler, F., 1984. Anaerobic reduction of glycerol to propanediol-1,3 by Lactobacillus brevis and Lactobacillus buchneri. Syst. Appl. Microbiol. 5, 169-178.

Sekwati-Monang, B., Valcheva, R., Gänzle, M.G., 2012. Microbial ecology of sorghum sourdoughs: effect of substrate supply and phenolic compounds on composition of fermentation microbiota. Int. J. Food Microbiol. 159 (3), 240-246.

Selembo, P., Perez, J., Lloyd, W., Logan, B., 2009. Enhanced hydrogen and 1,3propanediol production from glycerol by fermentation using mixed cultures. Biotechnol. Bioeng. 104, 1098-1106.

Temudo, M., Poldermans, R., Kleerebezem, R., van Loosdrecht, M., 2008. Glycerol fermentation by (open) mixed cultures: a chemostat study. Biotechnol. Bioeng. 100 (6), 1088-1098.

Toraya, T., Kuno, S., Fukui, S., 1980. Distribution of coenzyme B12- dependent diol dehydratase and glycerol dehydratase in selected genera of Enterobacteriaceae and Propionibacteriaceae. J. Bacteriol. 141, 1439-1442.

Yang, F., Milford, H., Runcang, S., 2012. Value-added uses for crude glycerol-A byproduct of biodiesel production. Biotechnol. Biofuels 2012 (5), 13.

Yazdani, S., Gonzalez, R., 2007. Anaerobic fermentation of glycerol: a path to economic viability for the biofuels industry. Curr. Opin. Biotechnol. 18 (3), 213219. 